\title{
Measuring the Antarctic ozone hole with the new Ozone Mapping and Profiler Suite (OMPS)
}

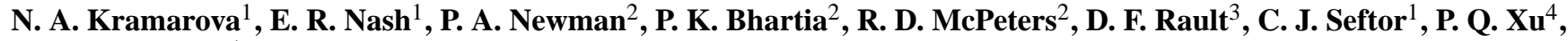 \\ and G. J. Labow ${ }^{1}$ \\ ${ }^{1}$ Science Systems and Applications, Inc., Lanham, Maryland, USA \\ ${ }^{2}$ NASA Goddard Space Flight Center, Greenbelt, Maryland, USA \\ ${ }^{3}$ Morgan State University, Baltimore, Maryland, USA \\ ${ }^{4}$ Science Applications International Corp., Beltsville, Maryland, USA
}

Correspondence to: N. A. Kramarova (natalya.a.kramarova@nasa.gov)

Received: 7 August 2013 - Published in Atmos. Chem. Phys. Discuss.: 10 October 2013

Revised: 28 January 2014 - Accepted: 31 January 2014 - Published: 6 March 2014

\begin{abstract}
The new Ozone Mapping and Profiler Suite (OMPS), which launched on the Suomi National Polarorbiting Partnership satellite in October 2011, gives a detailed view of the development of the Antarctic ozone hole and extends the long series of satellite ozone measurements that go back to the early 1970s. OMPS includes two modules - nadir and limb - to measure profile and total ozone concentrations. The new limb module is designed to measure the vertical profile of ozone between the lowermost stratosphere and the mesosphere. The OMPS observations over Antarctica show excellent agreement with the measurements obtained from independent satellite and ground-based instruments. This validation demonstrates that OMPS data can ably extend the ozone time series over Antarctica in the future. The OMPS observations are used to monitor and characterize the evolution of the 2012 Antarctic ozone hole. While large ozone losses were observed in September 2012, a strong ozone rebound occurred in October and November 2012. This ozone rebound is characterized by rapid increases of ozone at mid-stratospheric levels and a splitting of the ozone hole in early November. The 2012 Antarctic ozone hole was the second smallest on record since 1988.
\end{abstract}

\section{Introduction}

Since the middle of the 1980s, when the Antarctic ozone hole was first discovered (Farman et al., 1985), severe ozone depletion has been observed every austral spring over the
Antarctic region (Douglass et al., 2011). The levels of ozone depleting substances (ODSs) and the specific meteorological conditions control the development of the seasonal Antarctic ozone hole (Montzka et al., 2011; Douglass et al., 2011). The rapid ozone depletion in the spring, caused by heterogeneous chemical reactions, results in significant ozone loss at around $70 \mathrm{hPa}$ in October, with the depletion up to $98 \% \mathrm{com}-$ pared to the early 1970s period as observed over South Pole and Syowa stations (S. Solomon et al., 2005). The lowest total ozone concentration and the area of the Antarctic ozone hole, however, vary from year to year (Douglass et al., 2011). In 2002 the unique dynamical situation resulted in the first sudden stratospheric warming ever observed in the Southern Hemisphere (Newman and Nash, 2005). This situation led to the unusually high ozone concentration over Antarctica in 2002, despite high levels of ODSs.

Recently the levels of ODSs, primarily comprised of chlorine- and bromine-containing chemicals (Newman et al., 2007), have started to decline (P. Solomon et al., 2006; Jones et al., 2011; Montzka et al., 2011) as a result of the Montreal Protocol regulations. Some studies (e.g., Salby et al., 2011, 2012) have claimed that there is an upward ozone trend over the last decade in Antarctica. However, Hassler et al. (2011) showed that the first signs of ozone recovery will not be detectable earlier than 2017-2021, based on the analysis of ozonesonde measurements at the South Pole station. Hence, the continuation of satellite observations over Antarctica is critical in the next decades as the ozone hole is expected to 
show signs of recovery due to declining concentrations of ODSs.

Prior satellite instruments to measure profile and total column ozone have included the Total Ozone Mapping Spectrometer (TOMS), the Ozone Monitoring Instrument (OMI), the Solar Backscattered Ultraviolet instrument (SBUV/2), the Stratospheric Aerosol and Gas Experiment II (SAGE II) and two Microwave Limb Sounder (MLS) instruments (UARS and Aura). The Ozone Mapping and Profiler Suite (OMPS) represents the next generation of the US ozone monitoring system (Flynn et al., 2006). OMPS was designed to provide profile and total ozone products that meet the stringent requirements needed both for operational uses and to continue the long-term historical records. It began routine operations in 2012.

This study uses OMPS profile and total ozone observations to determine the temporal and spatial evolution of the 2012 Antarctic ozone hole. The main focus is to validate OMPS ozone observations in the Antarctic and to demonstrate the benefits of the synthesis of the three-instrument suite for more detailed monitoring of the Antarctic ozone hole.

The rest of this study is organized into four additional sections. A brief description of OMPS instruments is presented in Sect. 2. Section 3 shows results of the comparison of the OMPS observations over Antarctica against independent measurements. Section 4 investigates results of monitoring the 2012 ozone hole using OMPS measurements, including estimates of the lowest ozone concentration and the hole area. Conclusions are presented in Sect. 5.

\section{The Ozone Mapping and Profiler Suite (OMPS)}

OMPS was launched on 28 October 2011 on the Suomi National Polar-orbiting Partnership satellite. The instrumental suite is designed to measure the total column and the vertical distribution of ozone with high spatial and vertical resolutions. All three ozone sensors measure solar radiance in ultraviolet (UV) and visible ranges. They scan the same part of the atmosphere within a short period of time, making it easy to intercalibrate instruments and have a consistent record of total and vertical ozone measurements. The sensor suite has both nadir and limb modules. The nadir module combines two sensors: the Total Column Nadir Mapper (TC-NM) for measuring total column ozone, and the Nadir Profiler (NP) for ozone vertical profiles. The Limb Profiler (LP) module is designed to measure vertical ozone profiles with good vertical resolution $(1-3 \mathrm{~km})$ from the upper troposphere/lower stratosphere to the mesosphere. These modules are based on heritage designs: OMPS TC-NM is similar to TOMS and OMI, OMPS NP is similar to SBUV/2, and OMPS LP is similar to the Shuttle Ozone Limb Sounding Experiment flown on STS-87 and STS-107.

Both nadir sensors (TC-NM and NP) measure the UV radiance backscattered by Earth's atmosphere and surface, and they share some optical elements. The primary change in the OMPS nadir sensors is a switch from the traditional photomultiplier used previously in TOMS and SBUV/2 to a charge-coupled device (CCD) (Flynn et al., 2006).

The OMPS TC-NM sensor has a $110^{\circ}$ cross-track field of view (FOV), with 35 cross-track bins, and a $0.27^{\circ}$ alongtrack slit width corresponding to a $50 \mathrm{~km}$ resolution. It makes 400 swaths per orbit with 36 across-track measurements per swath, which allows for full global coverage every day. It has a spectral coverage over 300-400 nm. The OMPS TC-NM algorithm is very similar to the NASA version 8 TOMS algorithm used for OMI (Bhartia and Wellemeyer, 2002). The basic algorithm uses two wavelengths to derive total ozone: one wavelength with weak ozone absorption to characterize the underlying surface and clouds, and the other with stronger ozone absorption and sensitivity to the total column. The OMPS TC-NM algorithm uses ozone absorption cross sections based on Brion et al. (1993), whereas OMI and TOMS use older cross sections from Bass and Paur (1985).

The OMPS NP sensor has a $16.6^{\circ}$ cross-track FOV and a $0.26^{\circ}$ along-track slit width, giving cells of size $250 \mathrm{~km}$ by $250 \mathrm{~km}$ that are colocated with 5 central cells of the OMPS TC-NM sensor. OMPS NP obtains 80 measurements per orbit, resulting in full global coverage about every 6 days. It has spectral coverage of $250-310 \mathrm{~nm}$. The OMPS NP retrieval algorithm (by analogy with SBUV/2) uses 12 discrete wavelengths to retrieve ozone profiles employing the maximum likelihood (or optimal estimation) technique (Bhartia et al., 2013). Though the vertical resolution of the OMPS NP ozone retrievals is coarse, this sensor provides valuable middle stratosphere to mesosphere profiles, data for the continuation of the SBUV/2 data record, and validation of the OMPS LP retrievals.

The OMPS LP sensor measures solar radiances scattered from the atmospheric limb in the UV and visible spectral ranges. The UV wavelength measurements provide information about ozone concentration in the upper and middle stratosphere whereas visible wavelength measurements provide information on the lower stratosphere (McPeters et al., 2000). OMPS LP has three slits separated horizontally by $4.25^{\circ}$ (about $250 \mathrm{~km}$ ) to expand the sensor cross-track coverage. It makes about 160-180 measurements per orbit with 14 orbits per day, resulting in full global coverage every 3-4 days. Each slit provides a $1.85^{\circ}$ vertical FOV (corresponding to $112 \mathrm{~km}$ vertical extent at the tangent point), allowing for atmospheric coverage of $0-60 \mathrm{~km}$ plus an offset allowance. OMPS LP splits each vertical profile into two images: low altitude (bright) signals are measured with the small aperture, whereas the high altitude (low intensity) signals are measured with the large aperture. Measurements at short and long integration times are interleaved over the nominal 19s measurement duration (Jaross et al., 2012). All six spectra (three slits and two apertures) are captured onto a single focal plane. Three ozone profiles (one for each slit) are produced every $19 \mathrm{~s}$, which corresponds to a $1^{\circ}$ latitude 

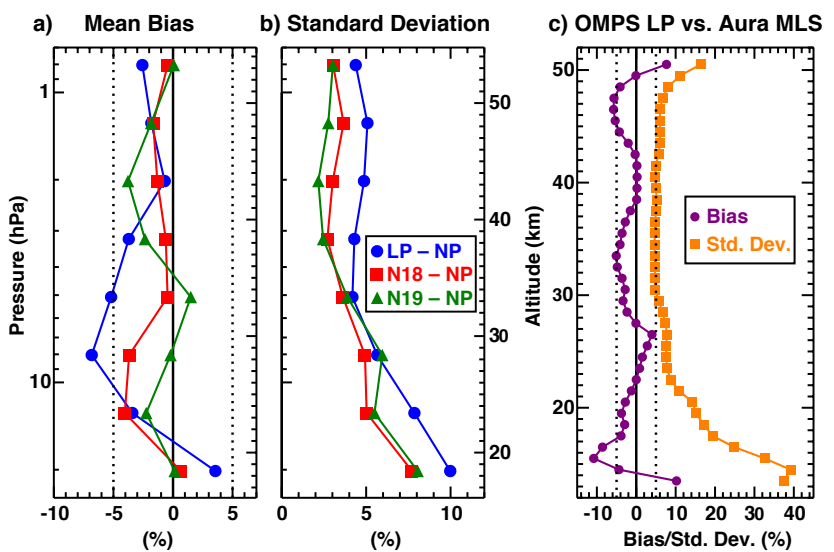

Fig. 1. Vertical profiles of the (a) mean differences and (b) corresponding standard deviations of the differences for OMPS LP (blue line and circles), SBUV/2 NOAA 18 (red line and squares), and SBUV/2 NOAA 19 (green line and triangles) against OMPS NP. (c) Vertical profiles of mean differences (purple line and circles) and standard deviations (orange line and squares) for comparisons between OMPS LP and Aura MLS. All data were compared over 55-82 ${ }^{\circ}$ S and September-November 2012.

sampling. To minimize the sensitivity to the underlying scene reflectance, measured radiances are first normalized with radiances measured at high altitudes (at $65 \mathrm{~km}$ in the UV and at $45 \mathrm{~km}$ in the visible). The OMPS LP ozone retrieval algorithm uses the pair/triplet method (Flittner et al., 2000; Rault, 2005).

\section{Validation of OMPS measurements}

OMPS measurements show excellent consistency both internally between modules and with other satellites. Of interest is the spatial and temporal extent of the seasonal Antarctic ozone loss. Figure 1 shows the validation of OMPS measurements for $55-82^{\circ} \mathrm{S}$ and September-November 2012. The latitudes are chosen because the 220-DU contour of total column ozone can extend to $55^{\circ} \mathrm{S}$ and the OMPS LP measurements can only reach poleward to $82^{\circ} \mathrm{S}$. Ozone loss generally starts in late August to early September and lasts until late November or early December. August measurements are not used because of the large area of polar night from which the instruments cannot obtain measurements. For each pair of comparing instruments, measurements are considered to be coincident if they are within $\pm 1^{\circ}$ latitude and $\pm 4^{\circ}$ longitude. Temporal criteria are different for each pair of instruments: $\pm 0.5 \mathrm{~h}$ for OMPS LP vs. OMPS NP, $\pm 1 \mathrm{~h}$ for OMPS LP vs. Aura MLS, and $\pm 4 \mathrm{~h}$ for SBUV/2 (NOAA 18 and NOAA 19) vs. OMPS NP comparisons. Table 1 summarizes results of the ozone profile comparisons. OMPS LP data (version 1) are reported as number densities (molecules $\mathrm{cm}^{-3}$ ) at 81 altitude levels with a step of $1 \mathrm{~km}$. Only profiles obtained from the central slit are considered in this study, and the altitude
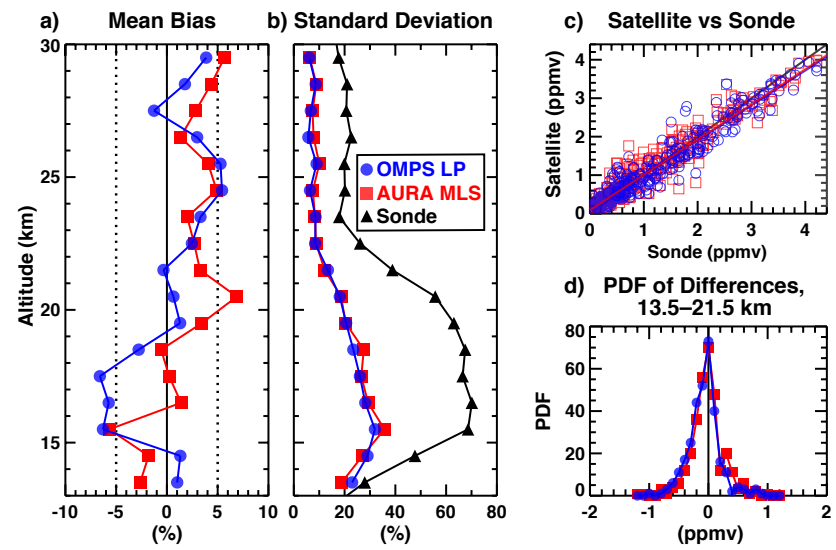

Fig. 2. Comparison of OMPS LP and Aura MLS against the ozonesonde balloon measurements from Neumayer $\left(70^{\circ} \mathrm{S}, 8^{\circ} \mathrm{W}\right)$ for September-November 2012. (a) Vertical profiles of mean differences and (b) standard deviations for OMPS LP (blue line and circles) and Aura MLS (red line and squares) relative to the sonde measurements. (b) also includes standard deviations of the sonde measurements relative to their time mean (black line and triangles). (c) OMPS LP and Aura MLS versus the sonde measurements in layers between 13.5 and $21.5 \mathrm{~km}$. (d) Probability density functions of the differences for OMPS LP and Aura MLS relative to the sonde measurements in layers between 13.5 and $21.5 \mathrm{~km}$.

range is limited from 14 to about $50 \mathrm{~km}$. OMPS NP data (version 1, NASA research processing) are reported as partial ozone columns (DUlayer ${ }^{-1}$ ) in $21 \mathrm{SBUV} / 2$ pressure layers. To compare OMPS LP and OMPS NP profiles the OMPS LP number densities are converted into partial ozone columns on the SBUV/2 grids. There is a good agreement between OMPS LP and OMPS NP measurements with the mean biases ranging from -6.3 to $3.6 \%$ (Fig. 1a, blue). The standard deviation of the differences (Fig. 1b, blue) is less than $5 \%$ between 1 and $10 \mathrm{hPa}$ and increases below this pressure range due to coarser OMPS NP vertical resolution in the lower stratosphere and troposphere (Kramarova et al., 2013). These results demonstrate a high consistency among the measurements obtained from OMPS LP and OMPS NP.

In addition, OMPS LP and OMPS NP measurements are compared against independent satellite observations: SBUV/2 and the Aura MLS. SBUV/2 has the same vertical resolution as OMPS NP and measurements can be compared directly. Comparisons of SBUV/2 (version 8.6) against OMPS NP demonstrate a good agreement with biases from -4.0 to $1.5 \%$ between 25 and $1 \mathrm{hPa}$ and standard deviations of $5-10 \%$ (Fig. 1a, b; red and green). Figure 1c shows results of the comparison between OMPS LP and Aura MLS (version 3.3). The OMPS LP number densities are converted into mixing ratios using National Centers for Environmental Prediction temperature profiles and MLS mixing ratio profiles are interpolated onto the OMPS LP vertical grids. The mean differences are mostly within $\pm 5 \%$ between 17 and $50 \mathrm{~km}$. The standard deviations are about $10 \%$ between 24 
Table 1. Summary of ozone profile comparisons over 55-82 ${ }^{\circ} \mathrm{S}$ in September-November 2012 (SD, standard deviation).

\begin{tabular}{llrrrr}
\hline Instrument 1 & Instrument 2 & Vertical range & $\begin{array}{c}\text { Bias } \\
\text { Instr. 1 - Instr. 2 } \\
\text { (\%) }\end{array}$ & SD & No. of points \\
& & & $\%)$ & 12534 \\
\hline OMPS LP & OMPS NP & $25-1 \mathrm{hPa}$ & -6.8 to 3.6 & $5-13$ & 5290 \\
SBUV/2 (NOAA 18) & OMPS NP & $25-1 \mathrm{hPa}$ & -4.0 to 1.1 & $5-10$ & 7494 \\
SBUV/2 (NOAA 19) & OMPS NP & $25-1 \mathrm{hPa}$ & -3.7 to 1.5 & $5-10$ & 8241 \\
OMPS LP & Aura MLS & $14-24 \mathrm{~km}$ & -10.8 to 1.5 & $10-40$ & 10 \\
OMPS LP & Neumayer sonde $\left(70^{\circ} \mathrm{S}, 8^{\circ} \mathrm{W}\right)$ & $14-22 \mathrm{~km}$ & -6.6 to 2.5 & $>10$ & 36 \\
& & $22-30 \mathrm{~km}$ & -1.3 to 5.4 & 10 & \\
\hline
\end{tabular}

and $48 \mathrm{~km}$ and increase below and above these levels (up to $40 \%$ in the lower stratosphere).

Figure 2 shows validations of OMPS LP ozone profiles in the lower stratosphere against Neumayer Station $\left(70^{\circ} \mathrm{S}\right.$, $\left.8^{\circ} \mathrm{W}\right)$ ozonesonde measurements. There are 36 balloon observations at Neumayer in the considered 3 month time period. Both OMPS LP and Aura MLS agree well with sondes throughout the entire altitude range from 14 to $30 \mathrm{~km}$. Biases vary from -6.6 to $5.4 \%$ (Fig. 2a). The standard deviations of the differences are $10 \%$ or less above $21 \mathrm{~km}$ and increase to $30 \%$ below (Fig. 2b). The black line in Fig. $2 b$ shows the standard deviations about the time mean of the sonde measurements and indicates greater ozone variability in the altitude range between 14 and $21 \mathrm{~km}$. Between 19 and $21 \mathrm{~km}$ OMPS LP agrees better with sondes than Aura MLS, but between 16 and $18 \mathrm{~km}$ OMPS LP underestimates ozone concentrations relative to both. Both satellite instruments, OMPS LP and Aura MLS, behave similarly relative to balloon measurements in the lower stratosphere (Fig. 2c, d).

Table 2 shows total ozone columns measured by OMPS TC-NM and OMPS NP validated against the corresponding independent observations obtained from OMI and SBUV/2. Mean biases are less than $1 \%$ with standard deviations of $3-4 \%$. The validation of OMPS total ozone and profile measurements against measurements from these other satellites demonstrate good agreement and indicate that the OMPS instruments provide very reasonable estimates of Antarctic ozone concentrations.

\section{OMPS ozone measurements of the 2012 Antarctic ozone hole: first results}

The OMPS TC-NM observations from 2012 continue the time series of total column observations that began with TOMS and continued with OMI. Figure 3 shows the monthly mean October 2012 total ozone amounts for OMI and OMPS TC-NM, along with the differences between them. The bias for measurements poleward of $55^{\circ} \mathrm{S}$ are relatively small, ranging from -3.6 to $4.9 \%$ (zonal mean biases are

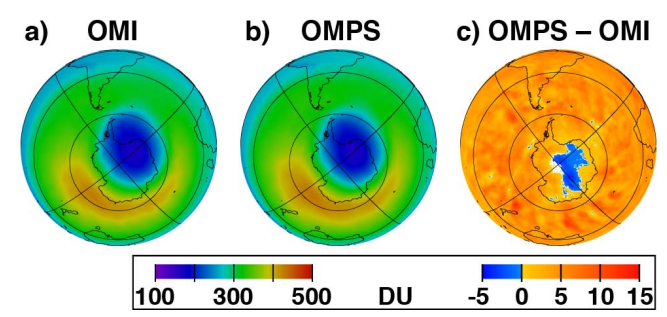

Fig. 3. Total column ozone from (a) OMI, (b) OMPS TC-NM, and (c) their difference (OMPS TC-NM-OMI) for October 2012.

shown in Table 2). OMPS is generally higher than OMI everywhere due to different ozone cross sections used in the OMPS and OMI algorithms (see Sect. 2). But near and within the ozone hole region OMPS TC-NM is lower in comparison to OMI. A preliminary analysis shows that OMPS overestimates reflectivity over ice and snow surfaces at large viewing angles, and as a result underestimates ozone column. Changes to the calibration of the OMPS TC-NM sensor will resolve this issue in the next released version of the data. Overall differences between OMPS TC-NM and OMI are quite small in comparison to the levels of column ozone loss that have been observed over Antarctica (> 50\%).

One of the primary metrics for assessing ozone depletion is the area contained within the 220-DU contour during the period from 7 September to 13 October (Newman et al., 2004). Figure 4 shows the area over this period for the years from 1979 through 2012. Two 2012 ozone hole area values are plotted: the OMI estimate of $17.8 \times 10^{6} \mathrm{~km}^{2}$ (black) and the OMPS TC-NM estimate of $17.6 \times 10^{6} \mathrm{~km}^{2}$ (red). The 2012 range of daily area values for OMPS (red) is 10.8$20.9 \times 10^{6} \mathrm{~km}^{2}$, while the range for OMI (black) is $11.2-$ $21.1 \times 10^{6} \mathrm{~km}^{2}$. The smaller area of the ozone hole measured by OMPS in comparison with OMI is consistent with the observed positive OMPS biases outside of Antarctica. The figure reveals two interesting aspects. First, the 2012 area was one of the smallest on record since the early 1990s. Only the 2002 area was smaller - a year with the first observed major sudden stratospheric warming in the Southern Hemisphere (Newman and Nash, 2005). Second, the area 
Table 2. Summary of total ozone comparisons poleward of $55^{\circ} \mathrm{S}$ and for September-November 2012.

\begin{tabular}{|c|c|c|c|c|c|c|c|c|}
\hline \multirow[t]{2}{*}{$\begin{array}{l}\text { Latitude } \\
\text { range }\end{array}$} & \multicolumn{2}{|c|}{$\begin{array}{c}\text { SBUV/2 NOAA } \\
18-\text { OMPS NP }\end{array}$} & \multicolumn{2}{|c|}{$\begin{array}{c}\text { SBUV/2 NOAA } \\
19-O M P S \text { NP }\end{array}$} & \multicolumn{2}{|c|}{$\begin{array}{l}\text { OMPS TC-NM- } \\
\text { OMPS NP }\end{array}$} & \multicolumn{2}{|c|}{$\begin{array}{l}\text { OMPS TC-NM- } \\
\text { Aura OMI }\end{array}$} \\
\hline & $\begin{array}{r}\text { Bias } \\
(\%)\end{array}$ & $\begin{array}{l}\text { SD } \\
(\%)\end{array}$ & $\begin{array}{r}\text { Bias } \\
(\%)\end{array}$ & $\begin{array}{l}\text { SD } \\
(\%)\end{array}$ & $\begin{array}{r}\text { Bias } \\
(\%)\end{array}$ & $\begin{array}{l}\text { SD } \\
(\%)\end{array}$ & $\begin{array}{r}\text { Bias } \\
(\%)\end{array}$ & $\begin{array}{l}\text { SD } \\
(\%)\end{array}$ \\
\hline $55-60^{\circ} \mathrm{S}$ & -0.9 & 3.3 & -0.8 & 3.2 & -0.9 & 2.5 & 1.4 & 1.3 \\
\hline $60-65^{\circ} \mathrm{S}$ & -0.5 & 4.0 & -0.7 & 3.5 & -0.6 & 3.4 & 1.2 & 1.1 \\
\hline $65-70^{\circ} \mathrm{S}$ & 0.3 & 4.6 & -0.4 & 3.6 & -0.2 & 3.4 & 0.9 & 1.2 \\
\hline $70-75^{\circ} \mathrm{S}$ & 0.6 & 4.0 & -0.3 & 3.6 & -0.1 & 3.7 & 0.8 & 1.4 \\
\hline $75-80^{\circ} \mathrm{S}$ & 1.0 & 3.5 & -0.5 & 3.0 & -0.4 & 4.3 & 0.6 & 1.8 \\
\hline$<55^{\circ} \mathrm{S}$ & 0.2 & 4.1 & -0.6 & 3.6 & -0.5 & 3.8 & 0.8 & 1.7 \\
\hline
\end{tabular}

of the ozone hole has stabilized and stopped growing since the mid-1990s, even though the level of active chlorine and bromine continued to grow until around 2000 (Newman et al., 2007). By the early 1990s active chlorine and bromine eventually reached the levels necessary to destroy $100 \%$ of the ozone in the lower Antarctic stratosphere. Thus further increase of chlorine and bromine levels could not make the ozone hole any larger. The Newman et al. (2006) parametric model has been updated using additional years of OMI and OMPS data (2006-2012) and recent observations of chlorine and bromine species in the estimate of equivalent effective stratospheric chlorine (EESC) (results are not shown here). The parametric model shows that after reaching saturation in the mid-1990s, the year-to-year ozone hole area variability has been mostly controlled by stratospheric temperature variability in the polar vortex collar region (specifically $50 \mathrm{hPa}$, $60-75^{\circ} \mathrm{S}$, and 21-30 September), in agreement with Newman et al. (2006). This analysis did not reveal any sign of ozone recovery over Antarctica. The small downward trend of the hole's area over the 1995-2012 period is not statistically distinguishable from a zero trend. The model predicts that the ozone recovery should become detectable (or statistically significant) sometime between 2015 and 2033, most likely in 2025.

During 2012, the ozone hole area increased normally during the August to early-September period, but diminished quite rapidly during the late-September to October period (compared to the last $20 \mathrm{yr}$ period). Figure 5a shows the daily estimates of the ozone hole area from the OMPS TC-NM (red) and OMI (blue). For the period 7 September-13 October, the OMPS TC-NM ozone hole area mean and standard deviation are $17.6 \times 10^{6}$ and $2.6 \times 10^{6} \mathrm{~km}^{2}$, respectively. The standard error between OMPS TC-NM and OMI ozone hole areas for the same period is $0.4 \times 10^{6} \mathrm{~km}^{2}$.

Figure $5 \mathrm{~b}$ shows that the minimum value of ozone, as with the area, fell at a somewhat slower rate in 2012, but stopped decreasing in about mid-September. Minimum values recovered more quickly than normal in October and were above normal levels by early December. Again, the OMPS TC$\mathrm{NM}$ and OMI minimum values were in close agreement. The range of absolute yearly minimum values occurs later than

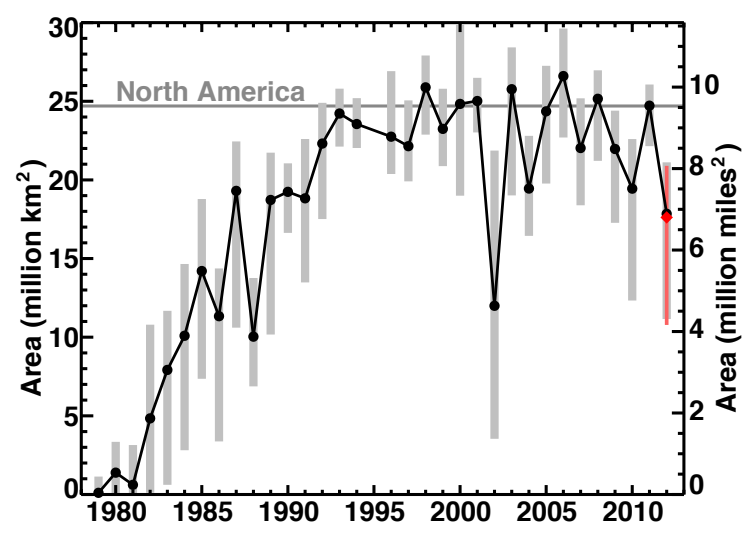

Fig. 4. Area of the Antarctic ozone hole from TOMS and OMI measurements (black circles), 1979-2012, and from OMPS (red circle) for 2012. These values are averaged from daily total ozone area values contained by the 220-DU contour for the 7 September-13 October period. The range of these daily total ozone area values are indicated for TOMS and OMI (gray shading) and OMPS (red shading in 2012).

the range of yearly ozone hole area maximum values. The OMPS TC-NM mean and standard deviation of the minima for the period 21 September-16 October are 137 and 13 DU, respectively. The standard error between OMPS TC-NM and OMI ozone minima for the same period is $1.8 \mathrm{DU}$.

Figure 6 shows the evolution of the 2012 Antarctic ozone hole. Total column ozone and ozone mixing ratios are chosen near the center of the polar vortex (Fig. 6a, b). The polar vortex is defined by NASA Global Modeling and Assimilation Office MERRA potential vorticity on the $460 \mathrm{~K}$ potential temperature surface. The location of the lowest total ozone near the center of the vortex, consistent with a smooth transition from day to day, is chosen for each day (see locations in Fig. 6c). During the vortex split in early November, the "blob" of vortex air that maintains itself the longest is followed. The vortex center remains in the range from -120 to $-30^{\circ} \mathrm{E}$ until the middle of October, then moves eastward through the vortex splitting, and ends up back in the same range in November as where it started in September. 


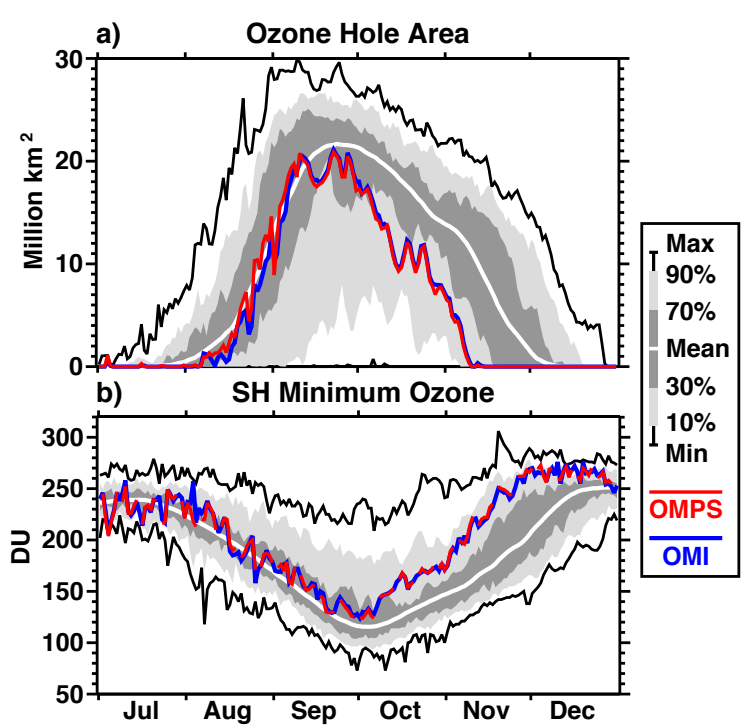

Fig. 5. (a) Ozone hole area and (b) minimum ozone for OMI (blue) and OMPS TC-NM (red) for 2012. Also shown are the daily climatological distributions for the period 1979-2011: the minimum and maximum (black lines), the 10-90 percentiles (light gray region), the $30-70$ percentiles (dark gray region), and the mean (thick white line).

Figure 6a (also Fig. 5b) shows that minimum total ozone occurs on 1 October and then increases through the OctoberNovember period. As has been shown by Hassler et al. (2011), there is a strong vertical gradient of ozone near $20 \mathrm{~km}$ (Fig. 6b). This gradient results from the very strong ozone depletion that occurs at altitudes below $22 \mathrm{~km}$. The minimum value in the profile occurs around $15 \mathrm{~km}$ - about 10 days after the total column minimum. There is a general steady increase in ozone at all levels starting from early October and proceeding through the end of November. The most dramatic increase occurs in the $25-30 \mathrm{~km}$ range, where mixing ratios almost double over this time period. Increases are much more modest in the lower stratosphere and level off by the middle of November.

The progression of ozone values during the austral spring is shown in Fig. 7 for both total column ozone (bottom row) and for three layers of the lower stratosphere. The gray vertical lines in Fig. 6 indicate days that are shown in Fig. 7. The white circles in Fig. 7 surround the point of the vortex used in the bottom panel of Fig. 6. On 2 September the ozone partial column values in the two upper levels correspond well to the total column ozone, while the lower-level ozone amounts are relatively high. By 19 September the partial column values are being depleted at all levels, and the ozone hole indicated by the total column shows deepening (bottom). By 4 October, near the minimum in total column ozone, all levels have had significant partial column value decreases, especially in the lowest layer.
The ozone hole area rapidly decreases in October and then splits into two parts. Note that the size of the low ozone area in the $26.5-29.5 \mathrm{~km}$ panels of Fig. 7 show a steady decline through the 2 September-21 November period. There is also a strong wave-1 warming event in October that displaces the vortex and the ozone hole off the pole. By 19 October the partial column values at the upper levels are starting to increase, while the lowest level retains low values. In early November a strong wave- 2 warming event splits the vortex and the ozone hole into two parts. The partial column values continue to increase at the upper levels through the end of November, while the partial column values at lower levels remain about the same.

Some have implied that the smaller ozone hole area results from a decrease in chlorine in the stratosphere (Salby et al., 2012). Inspection of Fig. 5 shows that the 2012 ozone hole develops at approximately the average rate during the August and early-September period. This is the period when chlorine chemical effects on the ozone hole area are most prominent (Newman et al., 2004; Kawa et al., 2009). These results indicate that the level of chlorine and bromine in the lower Antarctic stratosphere is high enough to cause severe ozone depletion. Current EESC levels in the Antarctic stratosphere are declining by about $30 \mathrm{pptyr}^{-1}\left(\mathrm{ppt}=10^{-12} \mathrm{~mol} \mathrm{~mol}^{-1}\right)$, less than $1 \% \mathrm{yr}^{-1}$ with respect to the Antarctic EESC peak of about 4040 ppt occurring around 2000 (Newman et al., 2007). Strahan et al. (2014) show that the level of chlorine can significantly vary (up to $\pm 5 \%$ ) from year to year due to interannual changes in the transport during austral fall and winter. Currently, the declines in chlorine levels are far too small to show an ozone hole recovery in comparison to yearto-year variability. Both the area and minimum values indicate a more rapid than normal ozone hole recovery in the late-September through November period. The ozone hole is strongly controlled by the wave dynamics and the direct influence of the waves on temperature (Newman et al., 2001, 2004; Weber et al., 2003). Strong wave events revealed in both the ozone distributions (wave-2 split in Fig. 7), and dynamical proxies such as the Eliassen-Palm flux (not shown) indicate that this more rapid recovery is dynamically driven. The smaller area in 2012 resulted from the warmer polar lower stratospheric temperatures in September and not chlorine decreases.

\section{Summary and conclusions}

The Ozone Mapping and Profiler Suite began routine operations in 2012. OMPS follows from the strong heritage of UV-visible satellite instruments that extend from the 1970s. OMPS is now the standard ozone-monitoring instrument aboard the US polar orbiting satellites.

OMPS observations agree well with standard measurements in the Antarctic region. First, direct comparisons of OMPS TC-NM and OMPS NP to the OMI and SBUV/2 total 

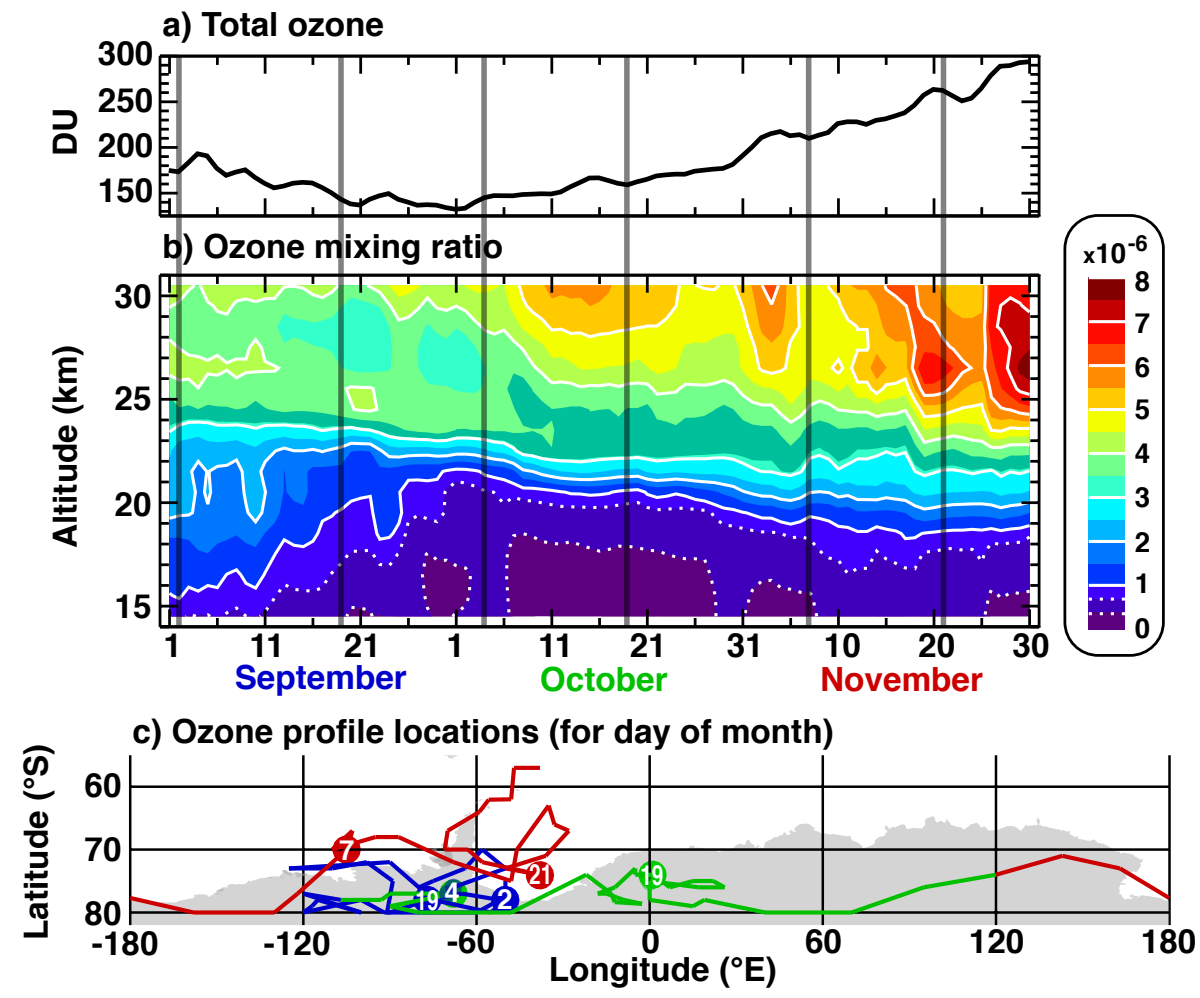

Fig. 6. (a) OMPS TC-NM total ozone and (b) OMPS LP ozone mixing ratios (14.5-30.5 km) for the 1 September-30 November 2012 period, derived from (c) a location chosen near the center of the polar vortex. In (c) the chosen locations are connected by colored lines: September (blue), October (green), and November (red). Vertical gray lines in (a) and (b) and circles in (c) indicate the days 2 September, 19 September, 4 October, 19 October, 7 November, and 21 November. The OMPS LP daily data have been smoothed in time by a 1-2-1 filter. The Antarctic continent is shaded in gray in (c) (adapted from Newman et al., 2013, Fig. 6.10).

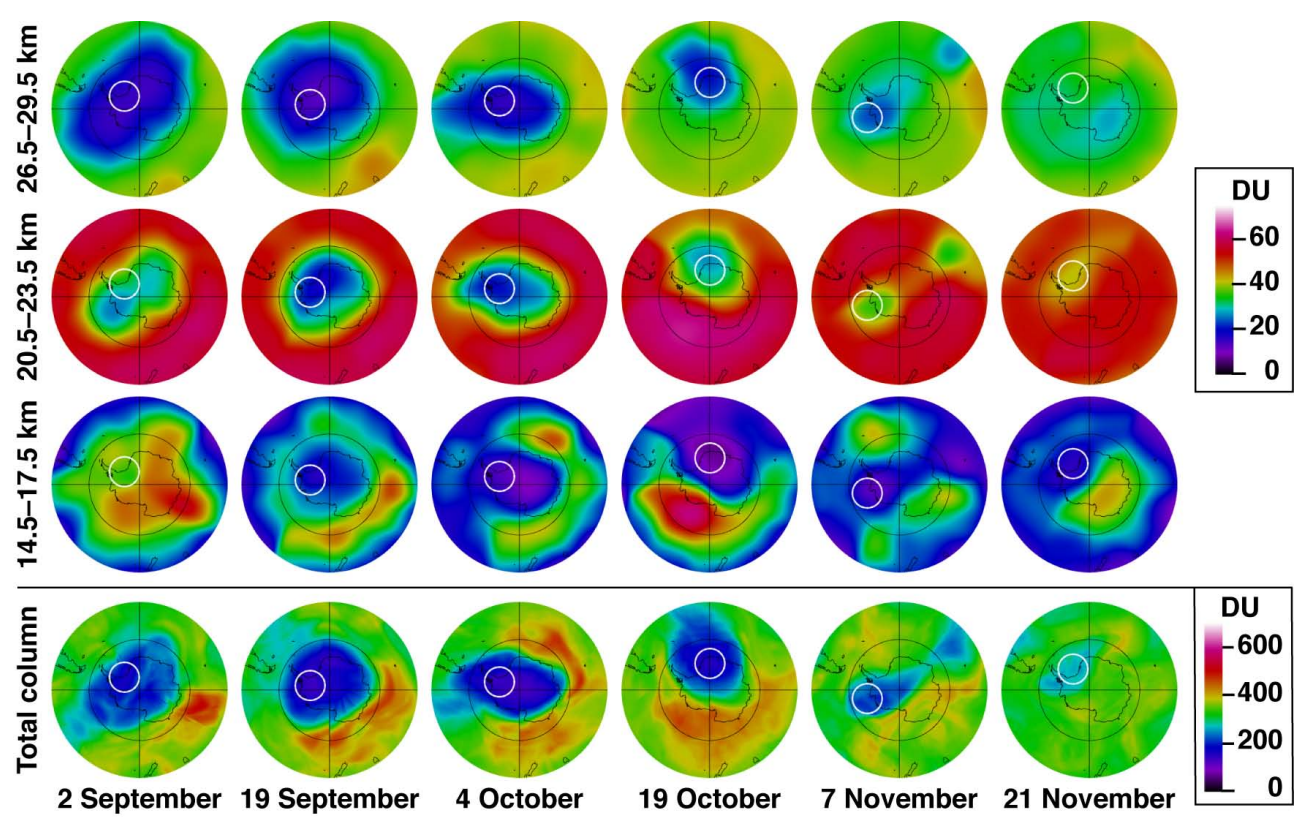

Fig. 7. OMPS LP column ozone amounts for 3 layers $(26.5-29.5 \mathrm{~km}, 20.5-23.5 \mathrm{~km}$, and $14.5-17.5 \mathrm{~km})$ and OMPS TC-NM total column ozone amounts for 2 September, 19 September, 4 October, 19 October, 7 November, and 21 November 2012. The white circles are within a radius of $1000 \mathrm{~km}$ of the center of the vortex for that day (see Fig. 6 for how the center of the polar vortex is determined). 
column observations show zonal mean differences generally less than $1 \%$. Second, the comparison of the OMPS profilers to the Aura MLS, SBUV/2, and ozonesondes shows differences of $7 \%$ or less between profiles from the upper stratosphere to the lowermost stratosphere $(13-45 \mathrm{~km})$. These comparisons give us good confidence in the ability of OMPS instruments to monitor the characteristics of the Antarctic ozone hole.

Estimates of ozone hole diagnostics from OMPS TC-NM are in excellent agreement with OMI observations. These estimates of the ozone hole's average size are within $0.2 \times$ $10^{6} \mathrm{~km}^{2}$ (about $1 \%$ ), while the value of the average minimum is within 1.2 DU. These excellent comparisons show that OMPS can continue the long-term Antarctic ozone hole time series. This continuation is critical for the next decade as the ozone hole begins to show signs of recovery.

The ozone hole developed quite normally in 2012, but because of the strong wave dynamics, faster warming during austral spring, and stronger advection, the 2012 ozone hole disappeared quite rapidly during the late-SeptemberNovember period as compared to the ozone holes of the last $20 \mathrm{yr}$. This stronger dynamical effect resulted in the second weakest ozone hole observed since 1988. The weakest ozone hole observed in this period was 2002 - driven by the first observed major stratospheric sudden warming in the Southern Hemisphere. The date of the 2012 ozone hole disappearance was also one of the earliest on record. The wave dynamics resulted in a splitting of the 2012 ozone hole during the early-November period (similar to the situation observed in late-September 2002, Newman and Nash, 2005). Because the development of the ozone hole in August and September is largely driven by the amounts of chlorine and bromine, the normal development of the ozone hole in August-September 2012 suggests that the ozone hole is not currently demonstrating a response to ODS declines, but is rather driven by the strong wave dynamics.

Acknowledgements. This work was supported under the NASA Atmospheric Chemistry Modeling and Analysis Program and the Modeling, Analysis, and Prediction Program. The Aura MLS science teams provided the high quality satellite ozone data set. The World Ozone and Ultraviolet Radiation Data Center (WOUDC) provided ozonesonde data. OMPS data are available at http://ozoneaq.gsfc.nasa.gov/omps. The MERRA data have been provided by the Global Modeling and Assimilation Office (GMAO) at NASA Goddard Space Flight Center through the NASA GES DISC online archive (http://disc.sci.gsfc.nasa.gov/daac-bin/DataHoldings.pl). Ozone maps, as well as statistical and climatological plots and data related to ozone, can be found at http://ozonewatch.gsfc.nasa.gov/. The authors wish to thank M. Weber and two anonymous referees for their constructive comments that helped to improve the paper.

Edited by: M. Weber

\section{References}

Bass, A. M. and Paur, R. J.: The ultraviolet cross-sections of ozone: I. The measurements, in: Atmospheric Ozone: Proceedings of the Quadrennial Ozone Symposium Halkidiki, Greece, 3-7 September 1984, edited by: Zerefos, C. S. and Ghazi, A., Reidel, Dordrecht, Holland, 606-610, doi:10.1007/978-94-009-5313-0_120, 1985.

Bhartia, P. K. and Wellemeyer, C. W.: TOMS-V8 total $\mathrm{O}_{3}$ algorithm, in: OMI Algorithm Theoretical Basis Document: OMI Ozone Products, edited by: Bhartia, P. K., ATBD-OMI-02, 1532, available at: http://www.knmi.nl/omi/documents/data/OMI ATBD_Volume_2_V2.pdf (last access: 28 February 2014), 2002.

Bhartia, P. K., McPeters, R. D., Flynn, L. E., Taylor, S., Kramarova, N. A., Frith, S., Fisher, B., and DeLand, M.: Solar Backscatter UV (SBUV) total ozone and profile algorithm, Atmos. Meas. Tech., 6, 2533-2548, doi:10.5194/amt-6-2533-2013, 2013.

Brion, J., Chakir, A., Daumont, D., Malicet, J., and Parisse, C.: High-resolution laboratory absorption cross section of $\mathrm{O}_{3}$ : Temperature effect, Chem. Phys. Lett., 213, 610-612, doi:10.1016/0009-2614(93)89169-I, 1993.

Douglass, A., Fioletov, V., Godin-Beekmann, S., Müller, R., Stolarski, R. S., Webb, A., Arola, A. Burkholder, J. B. Burrows, J. P., Chipperfield, M. P. Cordero, R., David, C., den Outer, P. N., Diaz, S.B., Flynn, L. E., Hegglin, M., Herman, J. R., Huck, P., Janjai, S., Jánosi, I. M., Krzyścin, J. W., Liu, Y., Logan, J., Matthes, K., McKenzie, R. L., Muthama, N. J., Petropavlovskikh, I., Pitts, M., Ramachandran, S., Rex, M., Salawitch, R. J., Sinnhuber, B.M., Staehelin, J., Strahan, S., Tourpali, K., Valverde-Canossa, J., and Vigouroux, C.: Stratospheric ozone and surface ultraviolet radiation, Chapter 2 in: Scientific Assessment of Ozone Depletion: 2010, Global Ozone Res. Mon. Proj., Report No. 52, World meteorological organization, Geneva, Switzerland, 76 pp., available at: http://www.wmo.int/pages/prog/arep/gaw/ozone_2010/ documents/chapter2.pdf (last access: 28 February 2014), 2011.

Farman, J. C., Murgatroyd, R. J., Silnickas, A. M., and Thrush, B. A.: Ozone photochemistry in the Antarctic stratosphere in summer, Q. J. Roy. Meteor. Soc., 111, 1013-1028, doi:10.1002/qj.49711147006, 1985.

Flittner, D. E., Herman, B. M., and Bhartia, P. K.: $\mathrm{O}_{3}$ profiles retrieved from limb scatter measurements: Theory, Geophys. Res. Lett., 27, 2601-2604, doi:10.1029/1999GL011343, 2000.

Flynn, L. E., Seftor, C. J., Larsen, J. C., and Xu, P.: The Ozone Mapping and Profiler Suite, in: Earth Science Satellite Remote Sensing, edited by: Qu, J. J., Gao, W., Kafatos, M., Murphy, R. E., and Salomonson, V. V., Springer, Berlin, 279-296, doi:10.1007/9783-540-37293-6, 2006.

Hassler, B., Daniel, J. S., Johnson, B. J., Solomon, S., and Oltmans, S. J.: An assessment of changing ozone loss rates at South Pole: Twenty-five years of ozonesonde measurements, J. Geophys. Res., 116, D22301, doi:10.1029/2011JD016353, 2011.

Jaross, G., Chen, G., Kowitt, M., Warner, J., Xu, P., Kelly, T., Linda, M., and Flittner, D.: Suomi NPP OMPS Limb Profiler initial sensor performance assessment, in: Proc. SPIE 8528, Earth Observing Missions and Sensors: Development, Implementation, and Characterization II, 852805, 28 November 2012, doi:10.1117/12.979627, 2012.

Jones, A., Urban, J., Murtagh, D. P., Sanchez, C., Walker, K. A., Livesey, N. J., Froidevaux, L., and Santee, M. L.: Analysis of $\mathrm{HCl}$ and $\mathrm{ClO}$ time series in the upper stratosphere using satellite 
data sets, Atmos. Chem. Phys., 11, 5321-5333, doi:10.5194/acp11-5321-2011, 2011.

Kawa, S. R., Stolarski, R. S., Newman, P. A., Douglass, A. R., Rex, M., Hofmann, D. J., Santee, M. L., and Frieler, K.: Sensitivity of polar stratospheric ozone loss to uncertainties in chemical reaction kinetics, Atmos. Chem. Phys., 9, 8651-8660, doi:10.5194/acp-9-8651-2009, 2009.

Kramarova, N. A., Bhartia, P. K., Frith, S. M., McPeters, R. D., and Stolarski, R. S.: Interpreting SBUV smoothing errors: an example using the quasi-biennial oscillation, Atmos. Meas. Tech., 6, 2089-2099, doi:10.5194/amt-6-2089-2013, 2013.

McPeters, R. D., Janz, S. J., Hilsenrath, E., Brown, T. L., Flittner, D. E., and Heath, D. F.: The retrieval of $\mathrm{O}_{3}$ profiles from limb scatter measurements: Results from the Shuttle Ozone Limb Sounding Experiment, Geophys. Res. Lett., 27, 25972600, doi:10.1029/1999GL011342, 2000.

Montzka, S. A., Reimann, S., Engel, A., Krüger, K., O’Doherty, S., Sturges, W. T., Blake, D., Dorf, M., Fraser, P., Froidevaux, L., Jucks, K., Kreher, K., Kurylo, M. J., Mellouki, A., Miller, J., Nielsen, O.-J., Orkin, V. L., Prinn, R. G., Rhew, R., Santee, M. L., Stohl, A., and Verdonik, D.: Ozone depleting substances (ODSs) and related chemicals, Chapter 1 in: Scientific Assessment of Ozone Depletion: 2010, Global Ozone Res. Mon. Proj., Report No. 52, World meteorological organization, Geneva, Switzerland, 108 pp., available at: http://www.wmo.int/pages/prog/arep/ gaw/ozone_2010/documents/chapter1.pdf (last access: 28 February 2014), 2011.

Newman, P. A. and Nash, E. R.: The unusual Southern Hemisphere stratospheric winter of 2002, J. Atmos. Sci., 62, 614-628, doi:10.1175/JAS-3323.1, 2005.

Newman, P. A., Nash, E. R., and Rosenfield, J. E: What controls the temperature of the Arctic stratosphere during the spring?, J. Geophys. Res., 106, 19999-20010, doi:10.1029/2000JD000061, 2001.

Newman, P. A., Kawa, S. R., and Nash, E. R.: On the size of the Antarctic ozone hole, Geophys. Res. Lett., 31, L21104, doi:10.1029/2004GL020596, 2004.

Newman, P. A., Nash, E. R., Kawa, S. R., Montzka, S. A., and Schauffler, S. M.: Will the Antarctic ozone hole recover?, Geophys. Res. Lett., 31, L12814, doi:10.1029/2005GL025232, 2006.
Newman, P. A., Daniel, J. S., Waugh, D. W., and Nash, E. R.: A new formulation of equivalent effective stratospheric chlorine (EESC), Atmos. Chem. Phys., 7, 4537-4552, doi:10.5194/acp7-4537-2007, 2007.

Newman, P. A., Kramarova, N., Nash, E. R., Long, C. S., Pitts, M. C., Johnson, B., Santee, M. L., Burrows, J., and Braathen, G. O.: Ozone depletion, in: State of the climate in 2012, B. Am. Meteorol. Soc., 94, S142-S146, doi:10.1175/2013BAMSStateoftheClimate.1, 2013.

Rault, D. F.: Ozone profile retrieval from Stratospheric Aerosol and Gas Experiment (SAGE III) limb scatter measurements, J. Geophys. Res., 110, D09309, doi:10.1029/2004JD004970, 2005.

Salby, M., Titova, E., and Deschamps, L.: Rebound of Antarctic ozone, Geophys. Res. Lett., 38, L09702, doi:10.1029/2011GL047266, 2011.

Salby, M. L., Titova, E. A., and Deschamps, L.: Changes of the Antarctic ozone hole: Controlling mechanisms, seasonal predictability, and evolution, J. Geophys. Res., 117, D10111, doi:10.1029/2011JD016285, 2012.

Solomon, P., Barrett, J., Mooney, T., Connor, B., Parrish, A., and Siskind, D. E.: Rise and decline of active chlorine in the stratosphere, Geophys. Res. Lett., 33, L18807, doi:10.1029/2006GL027029, 2006.

Solomon, S., Portmann, R. W., Sasaki, T., Hofmann, D. J., and Thompson, D. W. J.: Four decades of ozonesonde measurements over Antarctica, J. Geophys. Res., 110, D21311, doi:10.1029/2005JD005917, 2005.

Strahan, S. E., Douglass, A. R., Steenrod, S. D, and Newman, P. A.: Inorganic chlorine variability in the Antarctic and its impact on ozone hole recovery, Geophys. Res. Lett., in review, 2014.

Weber, M., Dhomse, S., Wittock, F., Richter, A., Sinnhuber, B.M., and Burrows, J. P.: Dynamical control of NH and SH winter/spring total ozone from GOME observations in 1995-2002, Geophys. Res. Lett., 30, 1583, doi:10.1029/2002GL016799, 2003. 